\title{
Spatial and temporal variation of extremely abundant maxima of precipitation in Hungary during the period between 1951 and 2010
}

\author{
Lakatos, L. ${ }^{1}$, Sümeghy, Z. ${ }^{3}$, Soltész, M. ${ }^{2}$ \& Nyéki, J. ${ }^{2}$ \\ ${ }^{1}$ University of Debrecen, Centre of Agricultural and Applied Economic Sciences, Department of Agricultural \\ Engeneering H-4032 Debrecen, Böszörményi 138, Hungary, lakatos@agr.unideb.hu \\ ${ }^{2}$ University of Debrecen, Institute of Horticulture, H-4032 Debrecen, Böszörményi 138, Hungary \\ ${ }^{3}$ University of Szeged, Department of Climatology and Landscape Ecology H-6722 Szeged, Egyetem u. 2.
}

\begin{abstract}
Summary: The study deals with the accumulated database of 16 meteorological stations in Hungary during a period of 60 years. The purpose was to reveal the spatial and temporal structure of the appearance of extreme values in the daily distribution of data concerning precipitation. We strived to answer the question whether the frequency of incidences of daily maxima did they change or not during the 60 year-long period in the main growing regions of the country. It is demonstrated on geographical maps how the size and frequency of precipitation episodes ensued, and what are the typical traits of changes in intensity as well as in frequency of happenings projected according to their spatial and temporal distribution.

From the point of view of fruit and vegetable growing, it is of prime interest what kind of frequency and intensity of changes occurred in precipitation. The temporal distribution of extremities though did not seem to change significantly in some areas, but the recognition of changes may help conspicuously the planning and the choice between alternatives of species and varieties as well as technologies of horticultural managements for the long run.

Extremely intense rains during a short time may cause erosion and stagnant water, thus we have to know what are the odds of risk.

The temporary distribution of changes helps us to judge upon the reality of anxieties, which are expected according to the existence of trends. Seasonal or monthly distribution is visualised by maps, what is expected and what is accidental as for a decision in planning. The spatial distribution of coefficients of variation help us to decide what is the local chance of extreme happenings at different parts of the country and what is its coefficient of uncertainty. The risk of any undertaking dependent on conditions of weather could be expressed numerically by a coefficient of risk.
\end{abstract}

Key words: spatial distribution, temporal distribution, precipitation, extreme value, daily maximum of precipitation, Kriging standard

\section{Introduction and survey of the literature}

The aim of the study is the investigation of the frequency of extremely abundant precipitations on the territory of Hungary. However, extremes, abundance and lack of precipitation, both may cause serious trouble in agricultural production, soil erosion and lack of drainage appear less frequently than drought in Hungary.

For the sake of objectivity in planning, we should decide whether the tendency of the climate getting more dry or not on the basis of investigating the meteorological database of the last 60 years. From this point of view, the upset of the hydrological balance may ensue at the same values of yearly means but with different or anomalous distribution. The frequent but small daily doses (1-2 $\mathrm{mm}$ ) of rain may result in drought because the loss by evaporation, whereas large rains $(>20 \mathrm{~mm})$ if infrequent may cause erosion and at the same time drought damage. For that purpose we registered the frequencies of daily maxima of precipitations between
1951 and 2010. The spatial and temporal distribution should answer this question.

The study of water supply of plants considering the balance between precipitation and evaporation as a tool of aid agricultural technologies is actual as literary sources prove it (Antal 2003, Nováki et al.1996, Varga-H. 2003, Kozmáné et al. 1995). Similarly interesting topic is the search for proofs referring to the consequences of climatic changes (Alföldi, 2003, Köles et al. 2003) especially the nature of drought periods (Urbán 1993), the scrutiny of the nature of drought periods regarding their stability of damages (Antal 1992). Results earned already much useful information for the practice (Petrasovits 1988, Antal-Szesztay 1996, PálfaiBoga-Sebesvári 1999, Pálfay 2002).

The climatic changes causing in temperature and water supply touched susceptibly the results of production in field crops, vegetables and fruits (Varga-Haszonits et al. 2000, Csomor-Lambert 1987), as being subject to the variation and distribution of the individual elements of 
weather during the season (Cselötei 1998, Szalóki 1991, Varga et al. 2001).

To recognise and estimate the risk of production in a region, we need information on the expected frequency and intensity of meteorological happenings, as droughts (VargaHaszonits et al. 2002). So we should know, what are the odds of long periods without precipitation at the region in question, similarly, what is the probability of their frequency and length (Váradi 1993).

Lack of humidity could be averted by irrigation, which needs investment and often impossible. Superfluous water is a less frequent but also deleterious with the stagnant water of erosion at sloping sites.

\section{Material and method}

The meteorological database of 1951-2010 has been processed. The data were collected by Countrywide Meteorological Service. We received the territorial macroclimatological characteristics of the whole country, but the local expositions are not included. The 60-year long period seems to be sufficient to conclude mathematically valid information for the interests of growers. The study registered the spatial as well as temporal changes on the net of 16 stations of measurements. The points were connected by iso-lines on the geographic map by means of the software developed for that purpose Surfer 7.0 and fitted to the background according to Kriging standard.

The statistical process of the temporal variations was the fitting of regressions and checked by the SPSS 11.0 software, visualised by figures drawn by the Excel program.

The search was performed by 4 steps:

- Excessive values of precipitation broken down to seasons and to territorial distribution.

- Analysis of the time series of the data and finding the variation of $\mathrm{CV}$ values.

- Setting the slope of the curves of regression (m) of the temporary relations.

- Checking the significance of the variation (Fisher test).

For characterising the variability of time series, the variability of coefficients of variation $(\mathrm{CV})$ data were used. For that purpose the quotient of the variability of time series and means of the coefficients of variation has used.

$$
C V=\frac{S}{\bar{X}} * 100
$$

Where $\mathrm{s}$ is the variability of the time series and $\bar{X}$ is the mean of the sample

\section{Results}

It is generally recognised that a precipitation less than daily $5 \mathrm{~mm}$ do not provide water during the summer time for the plants except a little freshness. Drought should be appear like that if the rain is not concentrated into larger doses. Copious, more than $20 \mathrm{~mm}$ doses repeated within a short period may also harm the vegetation. In intense fruit growing, scarce precipitation increases first of all the costs of production. On sloppy growing sites the erosion is threatening, on the valley bottom or heavy soils, stagnant water is a matter of concern causing losses of yield. Altogether, daily quantity of precipitation and the maximum of doses are decisive information for the growers.

Intensity of precipitation depends on the instability of the atmosphere. Acute downpours arise when the temperatures (and air humidity) of the layers are very different and the contrasting air-masses get into contact with each other within the clouds. An intense upward blast arises in the summer at high temperature and produce rains with a countrywide mean $81.5 \mathrm{~mm}$ of a 50 -year-long period. The second most endangered period of intense rainfall is the autumn with a mean maximum of $64.4 \mathrm{~mm}$. The third period is the spring with a mean maximum of $55.5 \mathrm{~mm}$. The winter is much less characterised with 36.6 maxima, and downpours are seldom.

In the spring, the highest daily maxima prevail over the SW and NE parts of the country (Figure 1). Sometimes they are higher the $70 \mathrm{~mm}$. On the contrary, SE and NW of the country are the lowest, where the highest value was less than $50 \mathrm{~mm}$. Going from SE towards NW at the middle part of the Tisza river, the maxima increase $(65 \mathrm{~mm})$, then in the western part of the Danube-Tisza region $50 \mathrm{~mm}$ is the daily maximum. According to that, at springtime, those three centres produced the highest quantities.

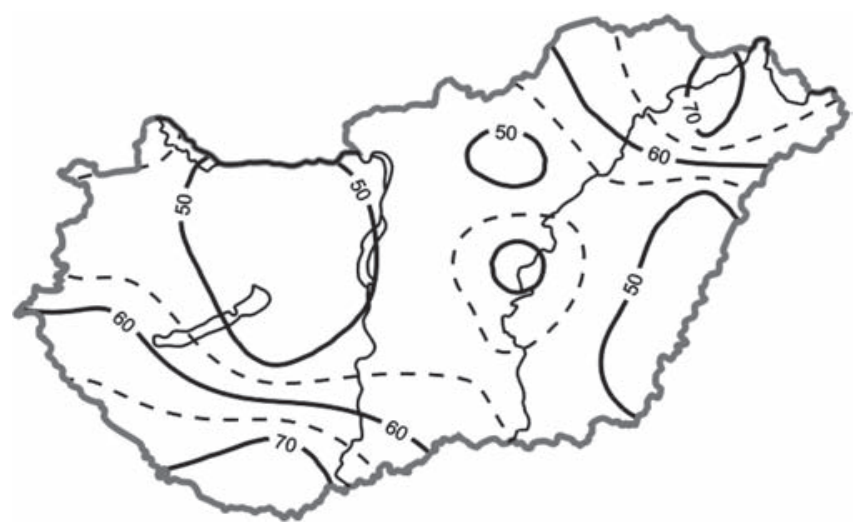

Figure 1 - The absolute daily maxima of precipitation in spring over 16 meteorological stations during the period of 1951-2010

During the summer were the largest doses of water often with daily maxima around $70 \mathrm{~mm}$, but meanwhile smaller downpours occurred on the same countryside (Figure 2).

In the Little Plain at the NW part of the country, furthermore in the Southern Transdanubia, counties Somogy and Tolna, there happened the highest downpours during the last years (more than $100 \mathrm{~mm} /$ day). Lowest daily maxima of precipitation were measured at the Viharsarok region (SE) around $60 \mathrm{~mm}$. Starting from there, the daily maximum quantity of precipitation is growing to the north gradually.

(In Budapest, at 1963 Sept 8, $115 \mathrm{~mm}$ rainfall was measured). The most storm threatened area of Hungary is 


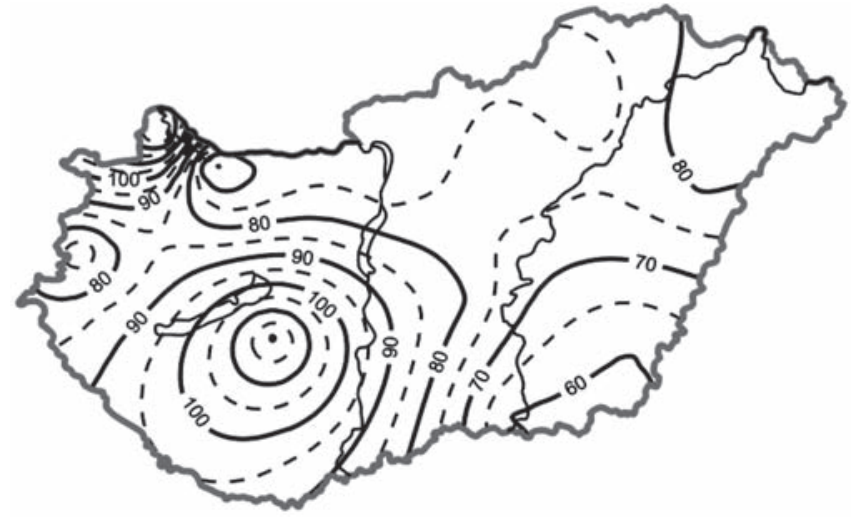

Figure 2 - The absolute daily maxima of precipitation in summer over 16 meteorological stations during the period of 1951-2010

the surrounding of Budapest (Figure 3). High daily maxima occur in the autumn around the SW corner (cca. $100 \mathrm{~mm}$ ) or NE Hungary (more than $80 \mathrm{~mm}$ ). The lowest daily maxima occur in the autumn around the SE corner.

During the winter, western Hungary, the Subalpine region, and in the northern part of the Great Plain, the highest maxima (more than $40 \mathrm{~mm}$ ), whereas the lowest daily maxima (less than $30 \mathrm{~mm}$ ) were found in the Danube-Tisza region (Figure 4).

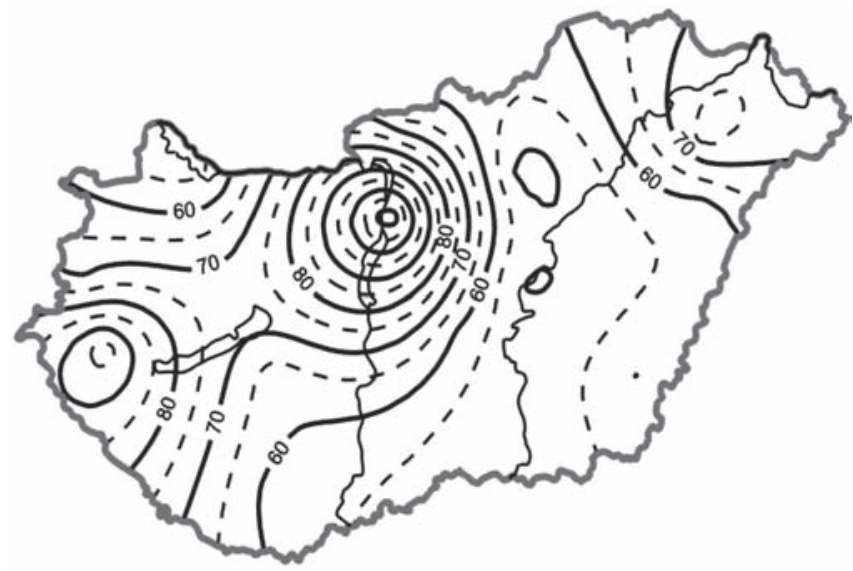

Figure 3 - The absolute daily maxima of precipitation in autumn over 16 meteorological stations during the period of 1951-2010

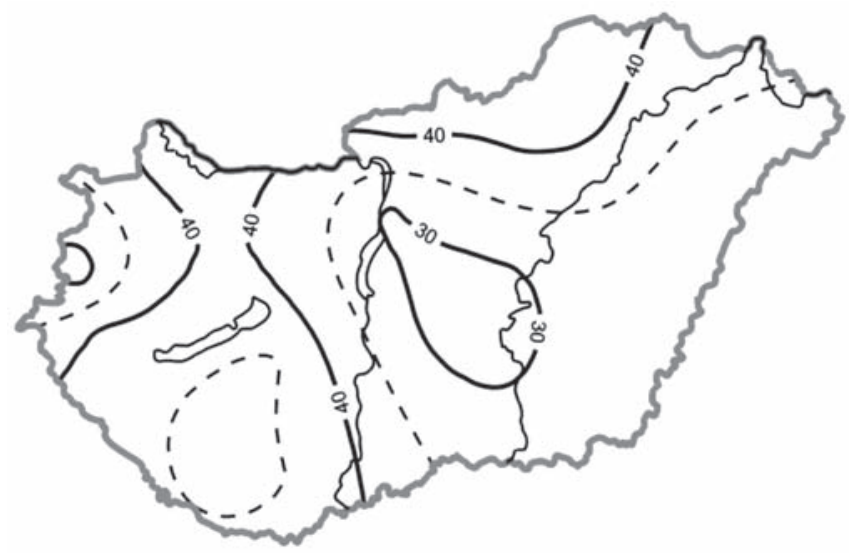

Figure 4 - The absolute daily maxima of precipitation in winter over 16 meteorological stations during the period of 1951-2010

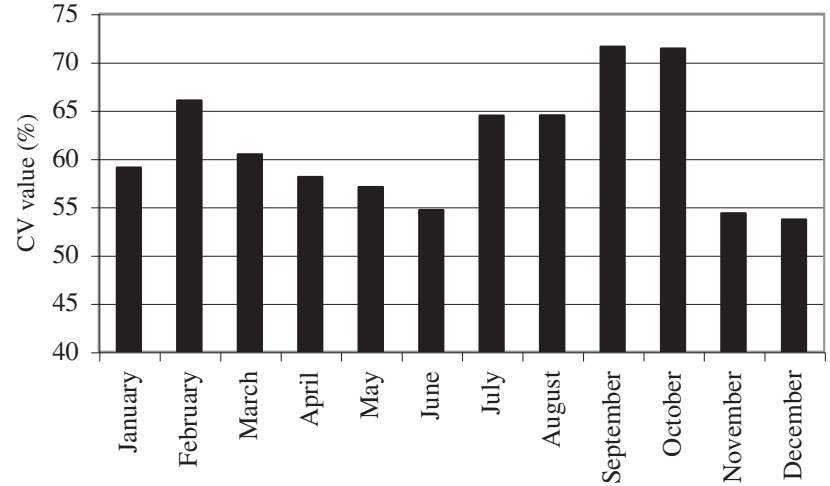

Figure 5 - The mean values of the coefficients of variation $(\mathrm{CV})$ of monthly maxima of precipitation in 16 stations over a period of 1951-2010

Not only the maximum values but also other differences occur between geographical areas but also during wintertime, where the lowest values were less than $20 \mathrm{~mm}$. The effect of the "basin" is revealed roughly as the centre of the DanubeTisza area displays the lowest values, but the northern mountains and the centre of Transdanubia produced higher daily maxima. The most variable meteorological element of Hungary is the precipitation. The seasonal variance is the largest in autumn (the mean is $46.2 \%$ ) and in winter it is the lowest (mean: $38.5 \%$ ) as shown in Table 1. Where the variability is higher, the water supply is more threatened by drought periods, thus the risk is higher.

Table 1 - Coefficients of variation of absolute daily maxima of precipitation raised at 16 stations in seasonal distribution over 1951-2010

\begin{tabular}{|l|c|c|c|c|}
\hline $\begin{array}{c}\text { ABS. MAX. PREC. } \\
\text { CV }\end{array}$ & spring & summer & autumn & winter \\
\hline Balassagyarmat & 40.51 & 37.51 & 44.91 & 39.96 \\
\hline Békéscsaba & 34.99 & 35.75 & 51.60 & 33.63 \\
\hline Budapest & 39.15 & 44.10 & $\mathbf{6 3 . 7 4}$ & 33.61 \\
\hline Debrecen & 45.64 & 44.91 & 53.58 & 31.34 \\
\hline Győr & 36.66 & 36.48 & 39.48 & 42.54 \\
\hline Iregszemcse & 42.76 & 52.71 & 43.40 & 41.85 \\
\hline Kecskemet & 46.78 & 44.98 & 43.91 & 30.40 \\
\hline Kompolt & $\mathbf{3 4 . 6 6}$ & 48.26 & 36.37 & 41.20 \\
\hline Miskolc & 35.32 & 36.35 & 46.14 & $\mathbf{5 0 . 2 3}$ \\
\hline Mosonmagyaróvár & 40.46 & 52.28 & 39.27 & 40.68 \\
\hline Nyíregyháza & $\mathbf{5 6 . 8 3}$ & $\mathbf{5 5 . 9 0}$ & 57.16 & 39.38 \\
\hline Pécs & 48.62 & 46.38 & 44.80 & 40.87 \\
\hline Szeged & 46.51 & 38.14 & 44.88 & 37.13 \\
\hline Szolnok & 49.77 & 42.63 & 42.20 & 34.20 \\
\hline Szombathely & 44.24 & $\mathbf{3 0 . 1 3}$ & 43.96 & 34.84 \\
\hline Zalaegerszeg & 40.28 & 35.97 & 43.19 & 44.02 \\
\hline min & $\mathbf{3 4 . 6 6}$ & $\mathbf{3 0 . 1 3}$ & 36.37 & $\mathbf{3 0 . 4 0}$ \\
\hline max & $\mathbf{5 6 . 8 3}$ & $\mathbf{5 5 . 9 0}$ & $\mathbf{6 3 . 7 4}$ & $\mathbf{5 0 . 2 3}$ \\
\hline difference & 22.17 & 25.77 & 27.38 & 19.83 \\
\hline mean & $\mathbf{4 2 . 7}$ & $\mathbf{4 2 . 7}$ & $\mathbf{4 6 . 2}$ & $\mathbf{3 8 . 5}$ \\
\hline
\end{tabular}


In autumn, the differences between the localities are the largest $(27.8 \%)$ whereas in the winter the smallest $(19.8 \%)$.

The monthly mean CVs (Coefficients of Variability) of the 16 stations shows clearly that in the autumn (September and October) variability of the daily maxima of precipitations is higher in the autumn, therefore the chance of abundant precipitation and also of drought periods is equally risked.

In spring, the NE part of the country excels with the highest (more than 50\%), whereas in the North, in the mountains, are the lowest (less than 40\%) the values of variability (Figure 6). The spatial structure develops on the axis SW-NE showing the largest variances. In Transdanubia, going from North to South, the variability increases but not more than by $5 \%$. East to the Tisza, the variability increases towards the NE direction. The direction of changes is there the opposite of that seen in Transdanubia. The difference between South and North approaches the value of $15 \%$ in the area east to the Tisza river.

The coefficient of variation of three months of the springtime are hardly different from each other. There is a slight diminution from March to May regarding the territorial means of the CVs $(60.4 \%$ to $57 \%)$

During the summer, the axis of two poles of the spring period becomes more accentuated, and the coefficients of variation increase, moreover a third pole appears. In the SW area (Somogy and Tolna counties), moreover in NE

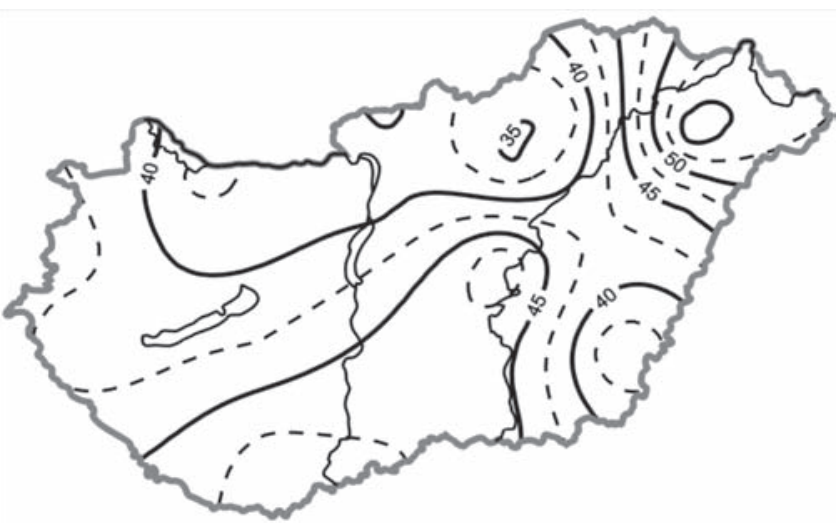

Figure 6 - The mean values of coefficients of variation $(\mathrm{CV})$ of the absolute daily maxima of precipitation in spring measured at 16 stations over a period of $1951-2010$

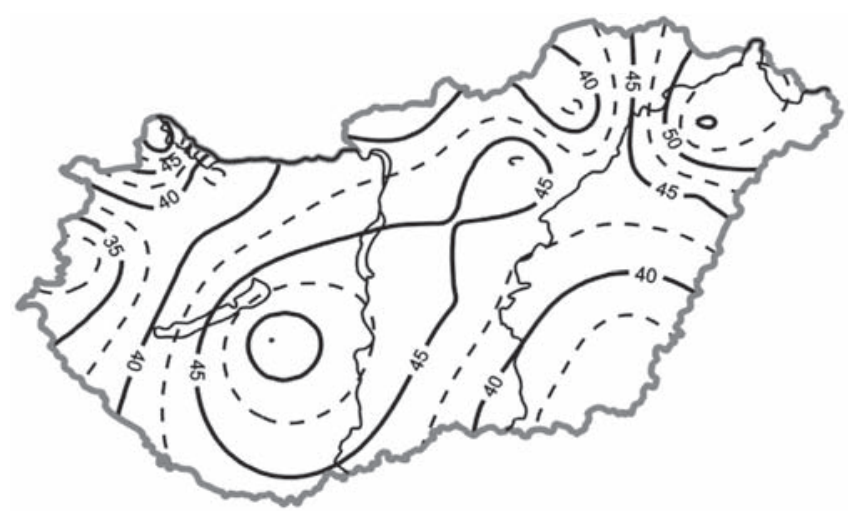

Figure 7 - The mean values of coefficients of variation (CV) of the absolute daily maxima of precipitation in summer measured at 16 stations over a period of $1951-2010$
(Nyírség) and in NW (Kisalföld) appear the highest CV values (between 50 and 55\%) (Figure 7).

The lowest variation was found during the summer near to the Subalpine region (W), Cserehát $(\mathrm{N})$ and Viharsarok (SE) with less than $40 \% \mathrm{CV}$ values.

The lowest point of $\mathrm{CV}$ values is in June, which may increase during the next two months by $10 \%$.

Between September and November, the mean of CV values falls from $72 \%$ to $54 \%$. The balance of humidity improves since evaporation diminishes markedly, moreover, the variability of precipitations declines too.

The three poles, which developed in summer will reduced to one pole in autumn. In the Budapest region the $\mathrm{CV}$ values increase to more than $60 \%$. In the region south to the Mátra mountain the $\mathrm{CV}$ sank to values less than $36 \%$. During autumn, in Transdanubia, the daily absolute maxima are changing scarcely their $\mathrm{CV}$, whereas East to the Tisza on the $\mathrm{W}-\mathrm{E}$ axis, $100 \mathrm{~km}$ means an increasing $\mathrm{CV}$ by $15 \%$ (Figure 8). The horizontal E-W gradient may attain $1.5 \%$ per $10 \mathrm{~km}$.

Between December and February, the absolute daily maxima of CV change from $54 \%$ to $66 \%$.

During winter, the eastern part of the central mountains (Cserehát, Zemplén-mountains) and the Subalpine region display the highest CV values (more than $45 \%$ ), whereas in the central region as Danube-Tisza region and the SE region we find the lowest values (around 40\%) (Figure 9).

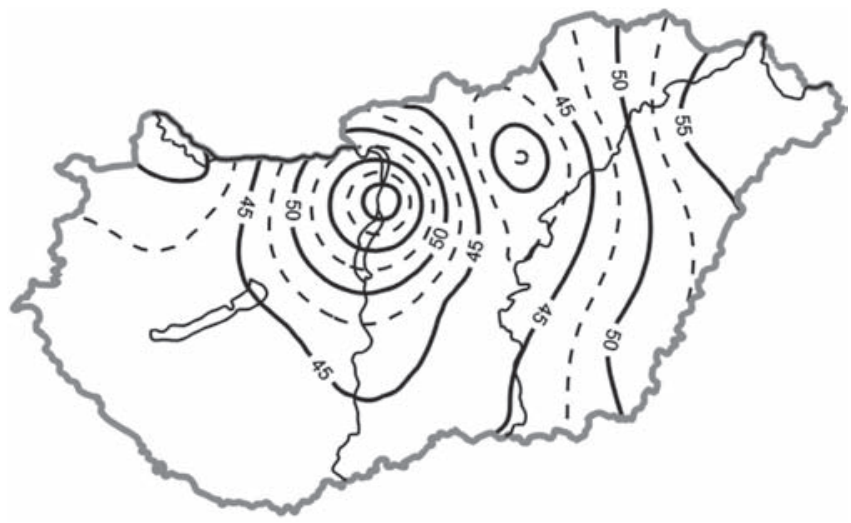

Figure 8 - The mean values of coefficients of variation $(\mathrm{CV})$ of the absolute daily maxima of precipitation in autumn measured at 16 stations over a period of 1951-2010

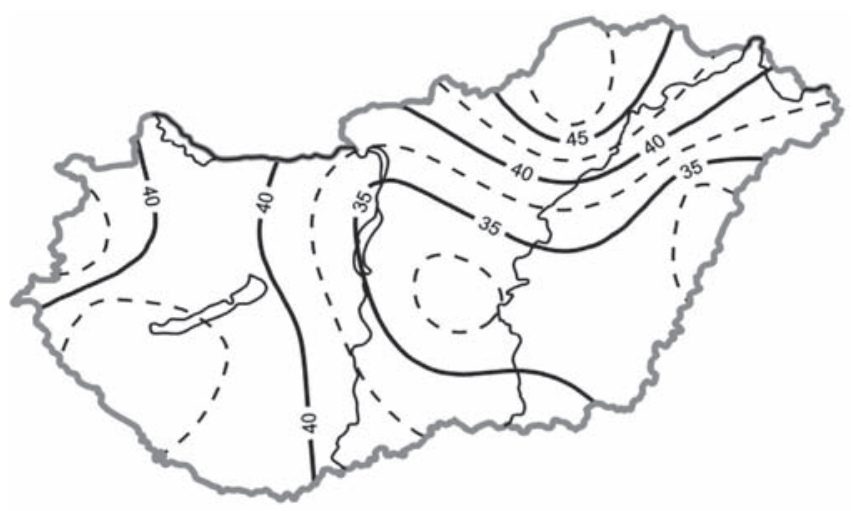

Figure 9 - The mean values of coefficients of variation (CV) of the absolute daily maxima of precipitation in winter measured at 16 stations over a period of 1951-2010 


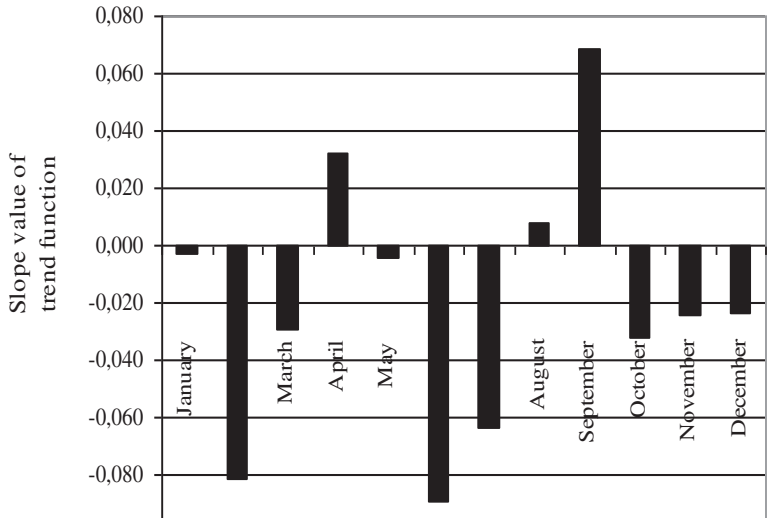

Figure 10 - The mean monthly slope values of the trend-function expressing the changes of the absolute maxima of precipitation according to data raised at 16 stations over 1951-2010

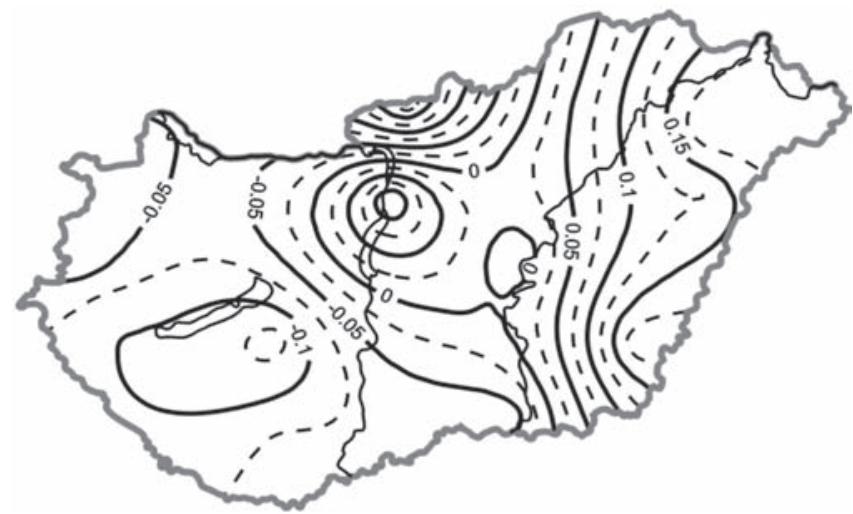

Figure 11 - The spatial distribution of mean daily slope values of the trend-function expressing the changes of the absolute daily maxima of precipitation in spring according to data raised at 16 stations over 1951-2010

In Transdanubia, $\mathrm{CV}$ values are almost the same, i.e. 35 $40 \%$, whereas in the northern part of the Great Plain the values increase by additional 20\%. Along the Debrecen-Miskolc axis, the horizontal increment of CV is nearly $2 \%$ per $10 \mathrm{~km}$.

As studying the trend of absolute daily maxima of precipitation, and the slope of changes, we may state that during the summer, the $2 / 3$ part of the country the values diminish, whereas in autumn, the values increase to the same extent, regarding the distribution of daily maximum precipitations. In spring and winter the increment and following decline shows the same spatial ratios. The sense of changes (increment or decline) in precipitation cannot be considered by no means to be homogenous. In some region, the increment of daily maxima, in another region the decline of the maxima could be observed. The most homogeneous spatial changes occur in February. In $94 \%$ of the database showed increment, but only in $25 \%$ of the stations was the change significant on the $95 \%$ level. Another highly homogeneous spatial change is found in June. In $75 \%$ of the stations observed, decline was observed, but only $25 \%$ of the cases proved to be significant on the $95 \%$ level.

The mean slope of the monthly changes in the 16 stations, we are able to state that the increment of the absolute daily

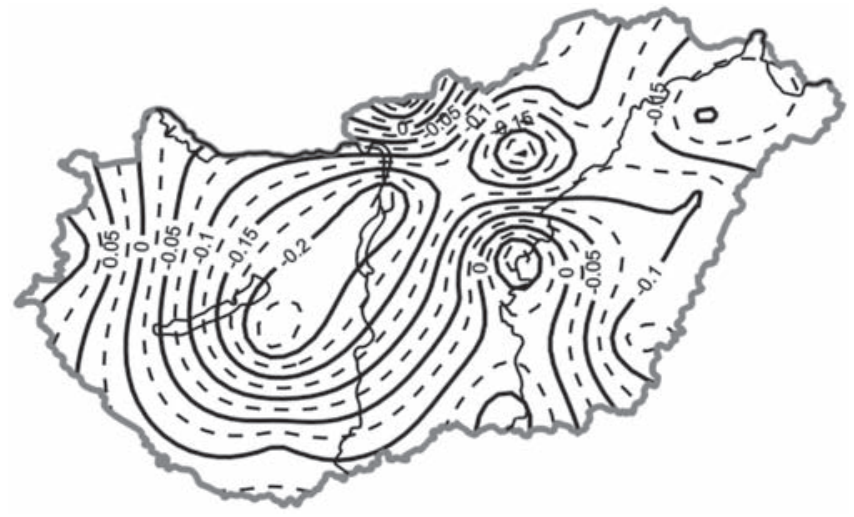

Figure 12 - The spatial distribution of mean daily slope values of the trend-function expressing the changes of the absolute daily maxima of precipitation in summer according to data raised at 16 stations over 1951-2010

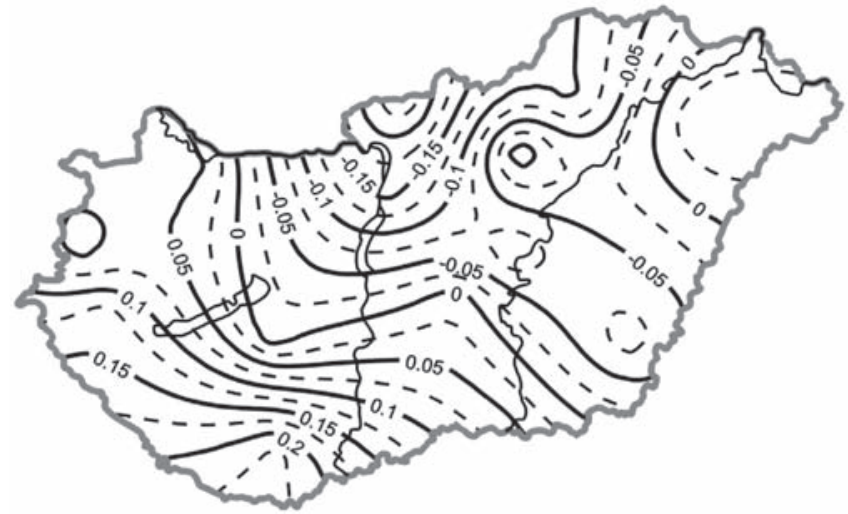

Figure 13 - The spatial distribution of mean daily slope values of the trend-function expressing the changes of the absolute daily maxima of precipitation in autumn according to data raised at 16 stations over 1951-2010

maximum precipitations culminates in September, whereas the decline is most marked in June and in February (Figure 10).

In springtime, the declines of daily absolute maxima are observed over Transdanubia, whereas an increment was found East of the Tisza region (Figure 11). On the region of Northern part of Great Plain the yearly increment of precipitation was more than $0.15 \mathrm{~mm}$. Nearly the same values of a declining trend were observed in South Transdanubia (Somogy county). The yearly decline is about $0.13 \mathrm{~mm}$. During the spring, the daily maximum of precipitation increased, and the change was in $25 \%$ of stations significant on the $95 \%$ level.

In summer, most decline of the absolute daily maxima was in the central region of Transdanubia (Figure 12). The declining tendency is expanding towards north, especially to the Mátra region, where the daily regression of the maxima was more than $0.25 \mathrm{~mm}$. About the middle of the Tisza region, whereas on southern Great Plain a slight increment occurred (0.07-0.09 mm per day). Among the contrasting developments, in the central Transdanubia and NE parts declined the CV, which proved to be significant on the $95 \%$ level.

The autumnal daily maxima of precipitation displays clearly the "basin" effect. Going from SW to NE, the 
increasing tendency is revealed until the line drawn between the towns Györ-Szeged declines gradually rising tendency of precipitations - where along a SE-NW, $100 \mathrm{~km}$ wide axis the decline prevails - then, in the Nyirség region, increases again (Figure 13).

In two-third of the country's area, the majority of the Transdanubian regions - except the NEastern part - at the southern part of the Danube-Tisza and north of the left bank of the Tisza, the absolute daily maxima of precipitations increased, whereas in the central northern region decreased during the 50 year long period.

Among the three autumnal months, in September, the increment of the daily maxima was most intense (mean was 0-07 mm/year), in October and November declined (0.03 $\mathrm{mm} /$ year). In southern Transdanubia, during autumn the daily maxima increased in county Baranya around Villány (at a rate of $0.2 \mathrm{~mm} /$ year or more), at the a same time to the north, county Nógrád and the hills of Cserhát the decline was found of the same magnitude $(0.2 \mathrm{~mm} /$ year $)$.

The two strongest changes of opposite sense are significant on the $95 \%$ level.

The decline of daily precipitation maxima during the winter is most conspicuous in February but only $20 \%$ of cases were significant concerning the diminution. On the contrary, in December and January none of the stations showed significant data concerning changes.

During the winter, in southern Transdanubia, the values of absolute daily maxima of precipitation increased, whereas in northern Hungary decreased (Figure 14). The decline is more accentuated $(0.16 \mathrm{~mm} /$ year $)$ than the increment $(0.11$ $\mathrm{mm} /$ year). The least change $(0-0.05 \mathrm{~mm} /$ year $)$ or even lack of change occurred in the southern Great Plain and in the centre of the Tisza region.

In the northern part of the Great Plain (Hernádvalley, Cserehát) there is a decline: $0.16 \mathrm{~mm} / \mathrm{year}$, which is significant on the $95 \%$ level. In the time series of other regions any significant change could be detected.

Regarding all the 16 stations, in February and June, the largest changes on the spatial sense were significant, 19\% in the daily maxima, whereas during the winter months, March, July and August none of the 16 stations signalised any changes significant on the $95 \%$ level (Figure 15).

The seasonal change of the absolute daily maxima of precipitation is presented as linear function of the trend, where the slope represents the intensity of changes on the singular stations. In Table 2 suggests that the increment is most intense in the autumnal period, whereas in spring and winter the half of stations experienced increment was recognised but decline in the other half of stations. During the summer period, two third of the stations signalised decline of the absolute daily maxima of precipitation. The summer displayed the tendency of getting more dry in the middle and the northern areas of Hungary. The most decline of the daily maxima of precipitation was found in the region south of the Mátra mountains. The increasing of daily maxima was most expressed in the spring on the data series of Nyíregyháza (Table 2).

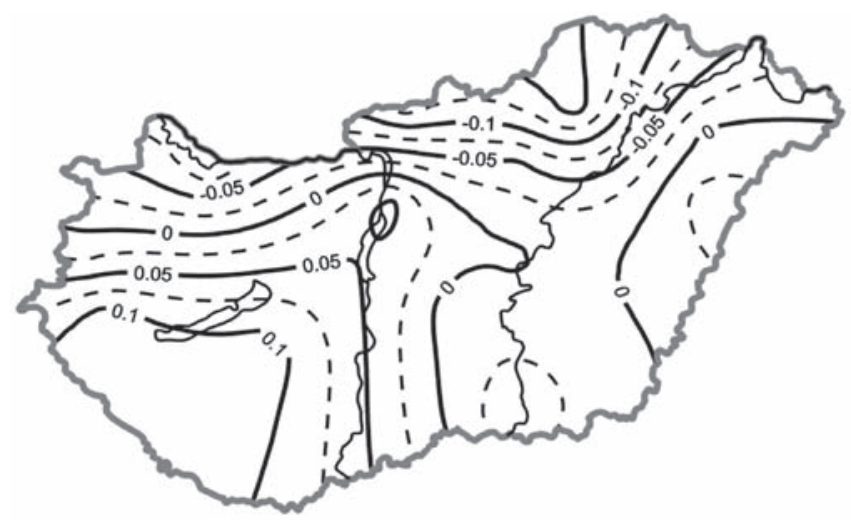

Figure 14 - The spatial distribution of mean daily slope values of the trend-function expressing the changes of the absolute daily maxima of precipitation in winter according to data raised at 16 stations over 1951-2010.

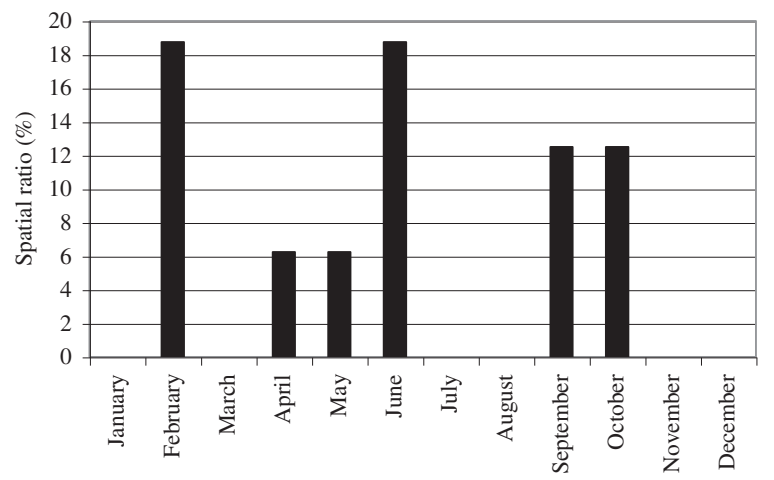

Figure 15 - The spatial ratio and monthly distribution of significant (95\%) changes of absolute daily maxima of precipitation according to data raised at 16 stations over 1951-2010

Table 2 - Slopes of the linear function in seasonal distribution expressing temporal changes of the absolute daily maxima of precipitation raised on data of 16 stations over the period of 60 years 1951-2010

\begin{tabular}{|l|r|r|r|r|}
\hline \multicolumn{1}{|c|}{$\begin{array}{c}\text { ABS. MAX. PREC. } \\
\text { slope }\end{array}$} & \multicolumn{1}{c|}{ spring } & summer & autumn & winter \\
\hline Balassagyarmat & -0.1983 & 0.1189 & $-\mathbf{0 . 2 4 7 7}$ & -0.1354 \\
\hline Békéscsaba & 0.1908 & -0.1344 & -0.0867 & -0.0051 \\
\hline Budapest & 0.1316 & -0.2421 & -0.1567 & 0.0579 \\
\hline Debrecen & 0.1242 & -0.0982 & $\mathbf{0 . 0 1 0 4}$ & 0.0324 \\
\hline Györ & -0.0594 & -0.0649 & 0.0479 & -0.0895 \\
\hline Iregszemcse & -0.1374 & -0.2520 & -0.0140 & 0.1084 \\
\hline Kecskemet & $\mathbf{0 . 0 0 7 0}$ & -0.0557 & 0.0192 & -0.0196 \\
\hline Kompolt & 0.0173 & $-\mathbf{0 . 2 7 0 7}$ & 0.0214 & -0.0510 \\
\hline Miskolc & 0.0577 & -0.0872 & -0.1046 & $-\mathbf{0 . 1 6 1 5}$ \\
\hline Mosonmagyaróvár & -0.0458 & -0.0254 & 0.0737 & -0.0759 \\
\hline Nyíregyháza & $\mathbf{0 . 2 0 0 5}$ & -0.2094 & 0.0527 & $-\mathbf{0 . 0 0 1 3}$ \\
\hline Pécs & -0.0653 & $\mathbf{0 . 0 0 2 4}$ & 0.2282 & 0.0964 \\
\hline Szeged & -0.0648 & 0.0730 & 0.0512 & -0.0388 \\
\hline Szolnok & -0.0232 & 0.1096 & -0.0952 & 0.0042 \\
\hline Szombathely & -0.0251 & 0.1165 & 0.0401 & 0.0192 \\
\hline Zalaegerszeg & -0.0960 & 0.0365 & 0.1366 & 0.1167 \\
\hline min & $\mathbf{0 . 0 0 7 0}$ & $\mathbf{0 . 0 0 2 4}$ & $\mathbf{0 . 0 1 0 4}$ & $-\mathbf{0 . 0 0 1 3}$ \\
\hline max & $\mathbf{0 . 2 0 0 5}$ & $-\mathbf{0 . 2 7 0 7}$ & $-\mathbf{0 . 2 4 7 7}$ & $-\mathbf{0 . 1 6 1 5}$ \\
\hline kül & 0.1935 & -0.2731 & -0.2581 & -0.1602 \\
\hline átlag & $\mathbf{0 . 0 0 0 9}$ & $-\mathbf{0 . 0 6 1 4}$ & $-\mathbf{0 . 0 0 1 5}$ & $-\mathbf{0 . 0 0 8 9}$ \\
\hline csökkenés aránya $\mathbf{\%})$ & $\mathbf{5 0}$ & $\mathbf{6 3}$ & 38 & 56 \\
\hline növekedés aránya $\mathbf{\%})$ & $\mathbf{5 0}$ & 38 & 63 & 44 \\
\hline
\end{tabular}


It is an important question to be answered that which are the stations, where the temporal series of data proves the significance of the changes regarding the absolute daily maxima of precipitation. The correlation between the fitted function of the trend and the measured data has been calculated, and the significance on the level of $\mathrm{P}=5 \%$ odds was in the spring and autumn proved in $12.5 \%$ of the stations (Table 3). The most conspicuous is the increment of absolute daily maxima of precipitation in the spring is found in the data series of Békéscsaba, whereas the most marked decline in autumn of the series at Balassagyarmat. During summer and winter, the values were lower and significant changes are found in $6.25 \%$ of the stations.

Table 3 - Coefficient of correlation between the fitted function of the trend and the measured data of absolute daily maxima of precipitation measured at 16 stations during the four seasons over a period of 1951-2010

\begin{tabular}{|l|c|c|c|c|}
\hline ABS MAX PREC corr eh. & spring & summer & autumn & winter \\
\hline Balassagyarmat & 0.29 & 0.14 & $\mathbf{0 . 3 1}$ & 0.26 \\
\hline Békéscsaba & $\mathbf{0 . 3 6}$ & 0.17 & 0.12 & $\mathbf{0 . 0 1}$ \\
\hline Budapest & 0.23 & $\mathbf{0 . 2 6}$ & 0.14 & 0.15 \\
\hline Debrecen & 0.18 & 0.09 & $\mathbf{0 . 0 1}$ & 0.10 \\
\hline Győr & 0.11 & 0.08 & 0.07 & 0.18 \\
\hline Iregszemcse & 0.21 & 0.19 & 0.02 & 0.19 \\
\hline Kecskemet & $\mathbf{0 . 0 1}$ & 0.06 & 0.03 & 0.05 \\
\hline Kompolt & 0.03 & 0.25 & 0.04 & 0.10 \\
\hline Miskolc & 0.10 & 0.09 & 0.14 & $\mathbf{0 . 2 7}$ \\
\hline Mosonmagyaróvár & 0.07 & 0.02 & 0.11 & 0.15 \\
\hline Nyíregyháza & 0.24 & 0.17 & 0.06 & 0.01 \\
\hline Pécs & 0.08 & $\mathbf{0 . 0 1}$ & 0.28 & 0.18 \\
\hline Szeged & 0.10 & 0.09 & 0.08 & 0.09 \\
\hline Szolnok & 0.03 & 0.11 & 0.14 & 0.01 \\
\hline Szombathely & 0.03 & 0.16 & 0.05 & 0.05 \\
\hline Zalaegerszeg & 0.13 & 0.04 & 0.15 & 0.21 \\
\hline min & $\mathbf{0 . 0 1}$ & $\mathbf{0 . 0 1}$ & $\mathbf{0 . 0 1}$ & $\mathbf{0 . 0 1}$ \\
\hline max & $\mathbf{0 . 3 6}$ & $\mathbf{0 . 2 6}$ & $\mathbf{0 . 3 1}$ & $\mathbf{0 . 2 7}$ \\
\hline diff & 0.35 & 0.25 & 0.29 & 0.26 \\
\hline mean & $\mathbf{0 . 1}$ & $\mathbf{0 . 1}$ & $\mathbf{0 . 1}$ & $\mathbf{0 . 1}$ \\
\hline sign (95\%) change was found & sign & sign & sign & sign \\
\hline Number of stations where & 2.5 & 6.25 & 12.5 & 6.25 \\
\hline Ratio of stations where & & & 2 & 1 \\
\hline sign. & & & & \\
\hline
\end{tabular}

\section{Conclusion}

It is prime interest to know what is the daily distribution of precipitations in time and space over the area of the country. The spatial changes show marked differences, which may find their explanation partly in orographical and partly rheological mechanisms. However, decline and increment of precipitation is variable not only spatially (regionally) but also seasonally or even monthly as determined by our climate. The tendency of springs getting drier is more symptomatic for the western or Transdanubian area, whereas in the eastern part of the country the increment of daily maxima of precipitations could be predicted.

The quantity, temporal and spatial distribution of precipitation is also highly variable. Generally, the tendency is significant in the northern part of the Great Plain, where the daily maxima of precipitations will decline, whereas in the southern part of Transdanubia a moderate increment of absolute daily maxima of precipitations was observed.

In autumn, the increment of daily maxima of precipitations is expected.

The temporal changes in daily maxima of precipitations are highly uncertain. The scrutiny of the database revealed that a general decline of notable extent on the countrywide level is valid especially referring to the central and northern part of the country, where the absolute daily maxima of precipitation decreased.

\section{Acknowledgement}

This study is funded by TECH_08-A3/2-2008-0373 and TECH_08-A4/2-2008-0138 projects.

\section{References}

Alföldi L. (2003): Gondolatok az éghajlatváltozás hidrológiai, vízgazdálkodási vonatkozásairól. „Agro-21” Füzetek, 32: 49-61.

Antal E. (1992): Az éghajlatváltozás hatása az aszályra Ma-gyarországon. Beszámolók az 1988-ban végzett tudományos kutatásokról. Országos Metetorológiai Szolgálat, Budapest. 156-164.

Antal E. (2003): Az éghajlatváltozás és a növényállományok vízellátottságának kérdőjelei a XXI. század elején. „Agro-21” Füzetek, 32: $25-48$.

Antal E., Szesztay K. (1996): Climate and water ecology. Időjárás 100: 193-206.

Cselötei L. (1998): Az időjárás hatása a növények vízellátottságára és termésére. Meteorológiai tudományos napok '98, OMSz, Budapest 7-14.

Csomor M. \& Lambert K. (1987): Mezőgazdasági növénykultúrák csapadékellátottsága a nyári hónapokban. Beszámolók az 1984ben végzett tudományos kutatásokról. Országos Metetorológiai Szolgálat, Budapest 181-187.

Köles P., Antal E. \& Dimény J. (2003): The impacts of the increasing drought frquency on the agricultural water management. Idojjárás. 107. (3-4): 237-248.

Kozmáné Tóth E., Posza I. \& Tiringer Cs. (1995): Szántóföldi növényállományok vízigénye, tényleges párolgása és öntözővíz szükséglete. Éghajlati és Agrometeorológiai Tanulmányok 3. OMSz, Budapest, 33-96.

Nováki B., Bussa A. \& Domonkos P. (1996): Éghajlati változások hatása az öntözővizigényre. Éghajlati és Agrometeorológia Tanulmányok 5: 108.

Pálfai I. (2002): Magyarország aszályossági zónái. Vízügyi Közlemények, 84. (3): 323-357. 
Pálfai I., Boga T.L. \& Sebesvári J. (1999): Adatok a magyarországi aszályokról 1931-1998. Éghajlati és Agrometeorológiai Tanulmányok 7. 67-77. OMSz, Budapest

Petrasovits I. (1988): Az agrohidrológia főbb kérdései. Akadémiai Kiadó, Budapest, 228 p.

Szalóky S. (1991): A növények vízigénye és öntözésigényessége. [In: Lelkes L., Ligetvári F. szerk.: Öntözés a kisgazdaságokban. Folium] Könyvkiadó Kft., Budapest, 21-42.

Urbán L. (1993): Az aszály fogalma és jelentősége. Beszámolók az 1989-ben végzett tudományos kutatásokról. Országos Metetorológiai Szolgálat, Budapest, 113-135.
Váradi F. (1993): Rövid időtartamú évi maximális csapadékhozamok statisztikai vizsgálata. Beszámolók az 1990-ben végzett tudományos kutatásokról. Országos Metetorológiai Szolgálat, Budapest. 194-210.

Varga-Haszonits Z., Varga Z. \& Lantos Zs. (2002): Az agroökoszisztémák és a meteorológiai küszöbértékek által meghatározott időszakok. Acta Agronomica Óváriensis. 44 (2): 103-119.

Varga-Haszonits Z. (2003): Az éghajlat változás mezőgazdasági hatásának elemzése, éghajlati szcenáriók. „AGRO-21” füzetek. Az Agrárgazdaság jövőképe. 31: 9-28. 